\title{
Effect of Span Length on the Impact Bending Strength of Poplar and Pine Woods
}

\author{
Bekir Cihad Bal
}

Solid wood is an important engineering material. Solid wood has superior properties, such as being renewable, easily processed, relatively inexpensive, and having higher mechanical properties relative to its density than any other engineering materials. Density, moisture content, tree species, knots, cracks, and some other variables influence the mechanical properties of wood. In this study, the effect of span length on the impact bending strength (IBS) of wood was investigated. Poplar and pine wood samples were used as test materials in the experiments. The IBS measurements were carried out following TS 2477 (1976) using a pendulum impact bending machine. Tests were conducted for various span lengths of $10,15,20,25,30$, and $35 \mathrm{~cm}$. The results indicated that there is a relationship between IBS and span length. The highest impact bending strength was obtained with a span length of $10 \mathrm{~cm}$ for poplar and pine wood. The relationship between IBS and span length was parabolic. The coefficients of determination were 0.94 and 0.99 for poplar and pine wood, respectively.

Keywords: Span length; Poplar wood; Pine wood; Impact bending

Contact information: Kahramanmaraş Sütçü Imam University, Vocational School of Technical Sciences, Kahramanmaraş, Turkey; *Corresponding author: bcbal@hotmail.com

\section{INTRODUCTION}

Solid wood has long been used as construction material. Physical properties (e.g., density, water absorption, and thickness swelling) and mechanical properties (e.g., modulus of rupture, modulus of elasticity, impact bending strength, hardness, tensile strength, compression strength, and fastener holding capacity) are the important technological properties of wood material. Impact bending strength is different from other mechanical properties, due to its loading type. Impact bending strength is related to dynamic loading, but the other qualities mentioned above are for static loadings.

Some variables, such as density, wood type, moisture content, fiber angle, test machine type, load direction, span-to-depth ratio, knots and cracks, densification, and tree species affect impact bending strength (Kollmann and Cote, Jr. 1968; Bal 2016; Gaff et al. 2016; Gašparík et al. 2016; Bal and Bektaş 2018; Çavuş 2020). Several previous studies have investigated the effect of these factors. Ghelmeziu (1938) investigated the effect of some factors such as annual ring width, span-to-depth ratio (slenderness), fiber angel, and density on the impact bending strength. Drow et al. (1965) determined that moisture content, density, and three species of test samples influenced the impact bending strength results. Kollmann and Cote, Jr. (1968) reported that density and moisture content of the wood affect the impact bending strength, especially the moisture content of $8 \%$ and $20 \%$. Bucar and Merhar (2015) determined that impact bending strength increases with the density of Norway spruce wood. Gaff et al. (2017) and Bal and Bektaş (2012) studied the 
effects of three species and adhesive type on the impact bending strength of LVL. Bal (2016) determined the impact bending strength of LVL in flatwise and edgewise directions for various span-to-depth ratios, and found a relationship between span-to-depth ratio and impact bending strength.

The effect of density, tree species, and moisture content of the wood or laminated wood on the impact bending strength (IBS) have been investigated in several studies. However, there has been a lack of published research examining the span length on impact bending strength. Therefore, the aim of this study is to investigate the effect of span length on the IBS of solid poplar and pine wood samples.

\section{EXPERIMENTAL}

\section{Materials}

In this study, poplar (Populus nigra) and pine (Pinus nigra) woods were used for preparing the test samples. Poplar and pine logs were purchased from a lumberyard in Kahramanmaraş, Turkey. Test samples were prepared to ensure homogeneity of groups according to the process shown in Fig. 1. The logs were cut into planks. The planks from sap wood were selected. The planks were dried for two months in an open shed, and then they were divided into slats with the dimensions of $2 \mathrm{~cm} \times 2 \mathrm{~cm} \times 150 \mathrm{~cm}$ (width, height, and length, respectively). Flawless slats without cracks and knots were chosen. The samples were prepared from these slats. Six test groups were prepared from the same slats. Thirty test samples were prepared for each group. The cross-sections of the test samples were $2 \mathrm{~cm} \times 2 \mathrm{~cm}$. The lengths of the test samples were 12,17, 22, 27, 32, and $37 \mathrm{~cm}$ (Fig. $1)$.

\section{Methods}

Samples were stored in a room at $20 \pm 3{ }^{\circ} \mathrm{C}$ and $65 \pm 5 \%$ relative humidity for five weeks, after which the tests were conducted. Values of air-dry density and impact bending strength were determined according to Turkish standards TS 2472 and TS 2477 (1976), respectively. Impact bending strength was determined using a pendulum-impact testing machine (ALŞA, Istanbul, Turkey) at various span lengths, such as 10, 15, 20, 25, 30, and $35 \mathrm{~cm}$.

IBS was calculated using Eq. 1. After the test, the moisture content of the samples was determined, and the IBS values were corrected using the strength conversion, Eq. 2, to reduce the effect of the moisture content on the results,

$$
\operatorname{IBS}=Q(a \times b)
$$

where IBS is impact bending $\left(\mathrm{kJ} / \mathrm{m}^{2}\right), Q$ is absorbing energy $(\mathrm{kJ}), a$ is the width of sample $(\mathrm{m})$, and $b$ is the thickness $(\mathrm{m})$. The impact bending at $12 \%$ moisture content was calculated as,

$$
\operatorname{IBS}_{12}=\operatorname{IBS}_{M}(1+\alpha(M-12))
$$

where $\mathrm{IBS}_{12}$ is the impact bending at $12 \%$ moisture content, $\mathrm{IBS}_{\mathrm{M}}$ is the impact bending at $\mathrm{M} \%$ moisture content, $\alpha$ is a constant ( $\alpha=0.025$ for impact bending), and $M$ is the moisture content of the test sample during the test. 


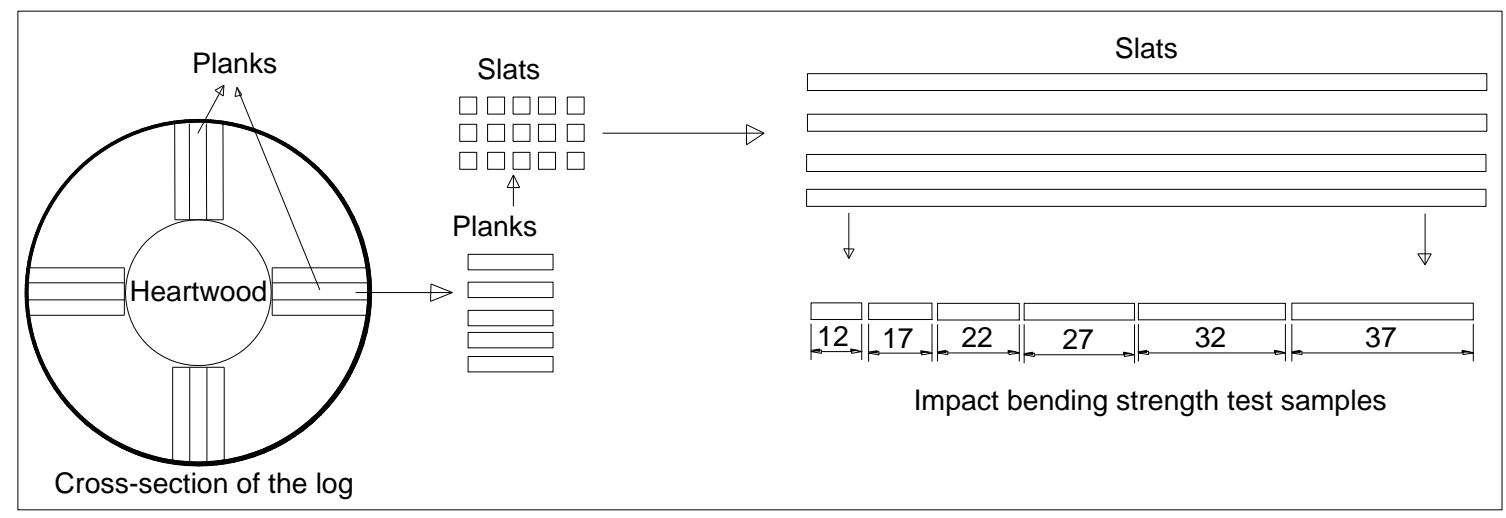

Fig. 1. Preparation of the impact bending strength test samples

The results were analyzed using One-way ANOVA tests to determine differences of IBS groups. The SPSS statistical software program was used to determine the effects of span length, and significant differences were determined by the Tukey HSD (Honestly Significant Difference) Multiple Comparison Test $(\alpha=0.05)$. In addition, the relationships between IBS and span length were analyzed with correlation using Excel program (Microsoft, Redmond, WA, USA).

\section{RESULTS AND DISCUSSION}

The results from density $(D)$ and impact bending strength (IBS) tests of poplar and pine wood samples for each group are presented in Table 1. It is clear from Table 1 that the densities of the poplar test groups ranged between 395 and $403 \mathrm{~kg} / \mathrm{m}^{3}$, and that of the pine test groups ranged between 483 and $490 \mathrm{~kg} / \mathrm{m}^{3}$. The differences among densities of test groups were insignificant. The $D$-values of all pine test groups were greater than those of the poplar groups.

The lowest impact bending strength attained was $36.1 \mathrm{~kJ} / \mathrm{m}^{2}$, which was obtained from pine wood. The highest impact bending strength was $55.3 \mathrm{~kJ} / \mathrm{m}^{2}$, which was obtained from poplar wood. In addition, the highest impact bending strengths of pine and poplar test groups were measured when the span length was at $10 \mathrm{~cm}$. The lowest impact bending strengths were measured when the span length was at $25 \mathrm{~cm}$. The differences among groups were statistically significant $(\mathrm{p}<0.001)$. But, only one group was different from other groups according to the Tukey test. The impact bending strengths of all poplar test groups was greater than that of pine test groups. The $D$-values of the pine samples were greater than those of poplar samples. It is well known that the mechanical properties of wood with high density are superior to that from wood with low density. However, in the present study, although the density of the pine wood was greater than that of the poplar wood, the impact bending strength of the poplar wood was greater than pine wood. The reason for this is the toughness of the material. Pine wood is more brittle than poplar wood. The cell type of the poplar wood is different from that of the pine wood. Therefore, even though the density of poplar wood was low, the impact bending strength of the poplar wood was measured as high. 
Table 1. Density (D) and Impact Bending Strength (IBS) Test Results for Each Test Groups, and Tukey Test Results Related to the Effects of Span Length

\begin{tabular}{|c|c|c|c|c|c|c|c|c|c|c|c|c|}
\hline Span & \multicolumn{2}{|c|}{10} & \multicolumn{2}{|c|}{15} & \multicolumn{2}{|c|}{20} & \multicolumn{2}{|c|}{25} & \multicolumn{2}{|c|}{30} & \multicolumn{2}{|c|}{35} \\
\hline Tests & D & IBS & D & IBS & D & IBS & D & IBS & D & IBS & D & IBS \\
\hline Units & $\mathrm{kg} / \mathrm{m}^{3}$ & $\mathrm{~kJ} / \mathrm{m}^{2}$ & $\mathrm{~kg} / \mathrm{m}^{3}$ & $\mathrm{~kJ} / \mathrm{m}^{2}$ & $\mathrm{~kg} / \mathrm{m}^{3}$ & $\mathrm{~kJ} / \mathrm{m}^{2}$ & $\mathrm{~kg} / \mathrm{m}^{3}$ & $\mathrm{~kJ} / \mathrm{m}^{2}$ & $\mathrm{~kg} / \mathrm{m}^{3}$ & $\mathrm{~kJ} / \mathrm{m}^{2}$ & $\mathrm{~kg} / \mathrm{m}^{3}$ & $\mathrm{~kJ} / \mathrm{m}^{2}$ \\
\hline Poplar & 395 & $55.3 a$ & 395 & $44.1 b$ & 398 & $41.7 \mathrm{~b}$ & 397 & $39.5 b$ & 403 & $42.0 \mathrm{~b}$ & 402 & $44.2 b$ \\
\hline wood & 26 & 9.4 & 22 & 7.4 & 20 & 7.8 & 21 & 7.8 & 31 & 12.6 & 20 & 10.9 \\
\hline Pine & 486 & $48.2 \mathrm{a}$ & 488 & $39.9 b$ & 490 & $36.1 \mathrm{~b}$ & 483 & $33.2 b$ & 484 & $35.7 b$ & 487 & $39.5 b$ \\
\hline wood & 27 & 12.6 & 39 & 11.0 & 79 & 10.3 & 62 & 9.3 & 35 & 8.4 & 45 & 10.4 \\
\hline
\end{tabular}

*The mean values are shown in bold, and standard deviations are shown in normal print

The relationship between IBS and span length is shown in Fig. 2. Regression equations are presented in the figure. The relationships between IBS and span length for pine and poplar could be expressed in polynomial form. The correlation was strong in both wood types. The coefficients of determination $\left(\mathrm{R}^{2}\right)$ for pine and poplar wood were 0.99 and 0.95 , respectively. The maximum value for IBS was obtained when the span length was at $10 \mathrm{~cm}$. The impact bending strength is at its lowest value when the span length was at $25 \mathrm{~cm}$. However, when the span length was greater than $25 \mathrm{~cm}$, the impact bending strength increased again, as shown in Fig. 3. Analogous studies related to solid wood were reported by Kollmann and Cote, Jr. (1968), who noted that the span-to-depth ratio ranges from 2 to 28, and the IBS of solid wood results in a parabolic change. Bal (2016) obtained lowest IBS values of LVL samples when the span-to-depth ratio was at 10. Monnin (1919) stated that toughness was expected to reach a minimum value at a span-to-depth ratio of 12. Ylinen (1944) discussed that the absorbed energy should be proportional to the volume of the beam span. According to the data attained from the present study, along with the results of previous studies, it can be stated that there is a strong relationship exists between impact bending strength and span length.

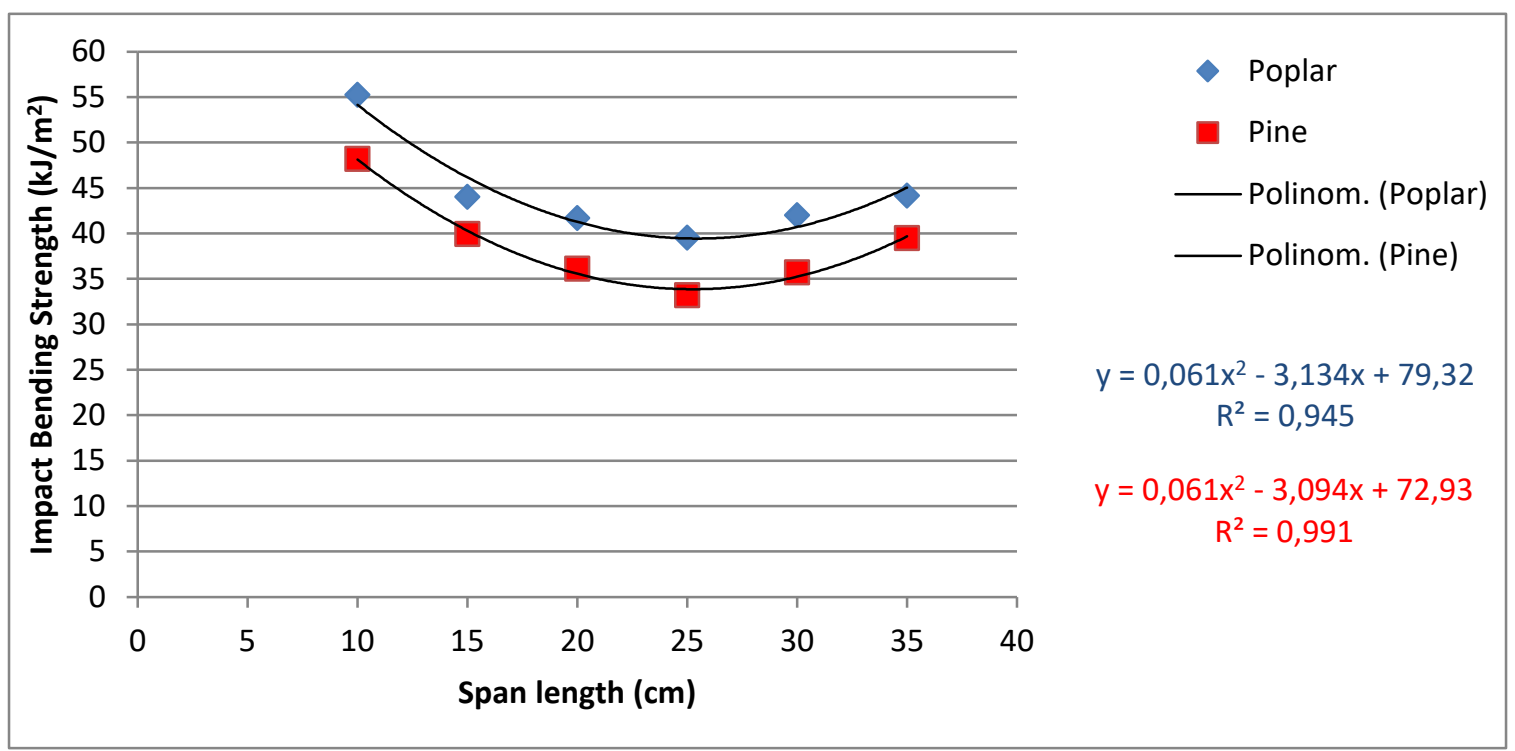

Fig. 2. The relationship between impact bending strength and span length 
The test samples were analyzed according to their fracture types after the IBS test. Poplar wood test samples were more fibrous than pine wood test samples, as can be seen in Fig. 3. No clear relationship between fracture type and span length was observed. In IBS test, type of rupture clearly characterized wood quality in the following way. Wood with high IBS showed long splinters. Fractured surfaces are plane, rather smoot in blunt woods (Kollmann and Cote, Jr. 1968).

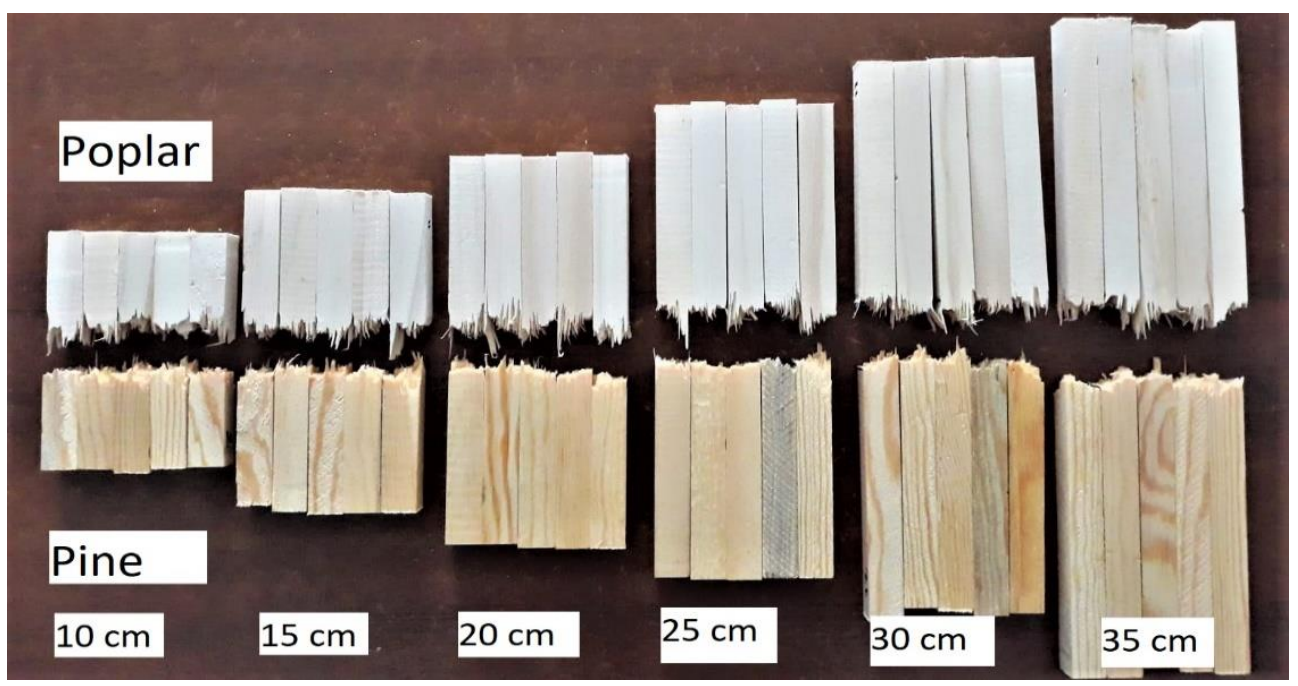

Fig. 3. Five test samples from each group after IBS test

\section{CONCLUSIONS}

This study investigated the effect of span length on the impact bending strength (IBS) of wood. In addition, the relationship between IBS and span length was also determined. According to data obtained, following conclusions can be made:

1. The effect of span length on the IBS was significant. The highest IBS was attained when the span length was at $10 \mathrm{~cm}$. The lowest IBS was seen when the span length was at $25 \mathrm{~cm}$.

2. The relationships between IBS and span length were polynomial. The correlation was strong in both wood types.

3. Although the density of pine wood was greater than that of poplar wood, the IBS of poplar wood was greater than pine wood.

\section{REFERENCES CITED}

Bal, B. C., and Bektaş, İ. (2012). "The effects of some factors on the impact bending strength of laminated veneer lumber," BioResources 7(4), 5855-5863. DOI: 10.15376/biores.7.4.5855-5863

Bal, B. C. (2016). "The effect of span-to-depth ratio on the impact bending strength of poplar LVL," Construction and Building Materials 112, 355-359. DOI: 10.1016/j.conbuildmat.2016.02.197 
Bal, B. C., and Bektaş, İ. (2018). “Odunun yoğunluğu ile bazı mekanik özellikleri arasındaki ilişkinin belirlenmesi üzerine bir araştırma," Mobilya ve Ahşap Malzeme Araştırmaları Dergisi 1(2), 51-61. DOI: 10.33725/mamad.467353

Bučar, D. G., and Merhar, M. (2015). "Impact and dynamic bending strength determination of Norway spruce by impact pendulum deceleration," BioResources 10(3), 4740-4750. DOI: 10.15376/biores.10.3.4740-4750

Çavuş, V. (2020). "Kokulu ardıç odununun bazı fiziksel ve mekanik özellikleri üzerine bir araştırma," Mobilya ve Ahşap Malzeme Araştırmaları Dergisi 3(1), 1-9. DOI: $10.33725 / \mathrm{mamad} .717060$

Drow, J. T., Markwardt, L. J., and Youngquist, W. G. (1965). Results of Impact Tests to Compare the Pendulum Impact and Toughness Test Methods (Report 2019), US Department of Agriculture, Forest Service, Forest Products Laboratory, Golden, CO, USA.

Gaff, M., Ruman, D., Záborský, V., and Borůvka, V. (2016). "Impact bending strength as a function of selected factors," BioResources 11(4), 9880-9895. DOI: 10.15376/biores.11.4.9880-9895

Gaff, M., Ruman, D., Svoboda, T., Sikora, A., Záborský, V., and Vallejo, C. R. (2017). "Impact bending strength as a function of selected factors: 2-Layered materials from densified lamellas," BioResources 12(4), 7311-7324. DOI:

10.15376/biores.12.4.7311-7324

Gašparík, M., Gaff, M., Šafař́ková, L., Vallejo, C. R., and Svoboda, T. (2016). "Impact bending strength and Brinell hardness of densified hardwoods," BioResources 11(4), 8638-8652. DOI: 10.15376/biores.11.4.8638-8652

Ghelmeziu, N. (1938). "Untersuchungen über die Schlagfestigkeit von Bauhölzern," Holz als Roh-und Werkstoff 1(15), 585-601.

Kollmann, F. F., and Cote, Jr., W. A. (1968). "Principles of wood science and technology," in: Principles of Wood Science and Technology, Vol. 1, SpringerVerlag, Berlin, Germany.

Monnin, M. (1919). "Essais physiques, statiques et dynamiques des bois," Bulletin de la Section Technique de l'Aéronautique Militaire, Paris.

TS 2472 (1976). "Wood-determination of density for physical and mechanical tests," Turkish Standard Institution, Ankara, Turkey.

TS 2477 (1976). "Wood-determination of impact bending strength,” Turkish Standard Institution, Ankara, Turkey.

Ylinen, A. (1944). Begründung der Abanderungsvorschlage der Prüfnormen für Holz, Silvae Orbis, Berlin-Wannseee, 15, 99.

Article submitted: February 17, 2021; Peer review completed: April 11, 2021; Revised version received and accepted: April 18, 2021; Published: April 20, 2021.

DOI: 10.15376/biores.16.2.4021-4026 